\title{
The effects of rainfall and vegetation on litterfall production in the semiarid region of northeastern Brazil
}

\author{
Lopes, MCA. ${ }^{a}$, Araújo, VFP. ${ }^{a}$ and Vasconcellos, A. ${ }^{a *}$ \\ ${ }^{a}$ Departamento de Sistemática e Ecologia, Centro de Ciências Exatas e da Natureza, \\ Universidade Federal da Paraíba - UFPB, CEP 58051-900, João Pessoa, PB, Brazil \\ *e-mail: avasconcellos@dse.ufpb.br
}

Received: November 13, 2013 - Accepted: May 28, 2014 - Distributed: August 31, 2015

(With 1 figure)

\begin{abstract}
Litterfall has a strong influence on biodiversity and on the chemical and physical characteristics of the soil. Its production can be quite variable over time and space, and can be influenced by both natural and anthropogenic factors. We evaluated litterfall production and its relationship with rainfall, species richness, and the densities of the arboreal vegetation. Thirty litter traps were constructed with $1.0 \mathrm{~m}^{2}$ nylon mesh $(1.0 \mathrm{~mm})$ and randomly installed within a $2000 \mathrm{~m} \times 500 \mathrm{~m}$ area of arboreal/shrub Caatinga (dryland) vegetation. Litter samples were collected monthly from November/2010 to June/2012, and the collected material was classified, dried, and weighted. Species richness and tree densities were determined by conducting phytosociological surveys in $20 \mathrm{~m} \times 20 \mathrm{~m}$ plots surrounding each of the litter traps. The litterfall accumulation rate was $3.673 \mathrm{Mgha}^{-1} \mathrm{yr}^{-1}$, similar to values from other seasonally dry tropical forests. Litterfall production was continuous, and principally accompanied the rainfall rate, but with a time interval of 2 to 3 months, with the greatest accumulation at the beginning of the dry season and the least during the rainy season. The different fractions of materials demonstrated distinct accumulation rates, with leaves being the principal category. Litterfall production was found to be related to tree density, but no link was found to species richness. The observed temporal heterogeneity of litterfall production demonstrated a strong link between rainfall and the dynamics of nutrient cycling in the semiarid region of Brazil.
\end{abstract}

Keywords: Caatinga, spatial variability, temporal variability, necromass, neotropical region.

\section{Efeitos da precipitação e da vegetação sobre a produção de serapilheira em uma área do semiárido do nordeste brasileiro}

\begin{abstract}
Resumo
A serapilheira exerce forte influência sobre a biodiversidade e as características físicas e químicas do solo. Sua produção pode ser bastante variável no tempo e no espaço e pode ser influenciada por fatores naturais e antropogênicos. Este estudo buscou avaliar a taxa de produção de serapilheira e a sua relação com a precipitação, riqueza de espécies e densidade da vegetação arbórea. No interior de uma área de $2000 \mathrm{~m} \times 500 \mathrm{~m}$ foram sorteados aleatoriamente 30 pontos amostrais e em cada um deles instalado um coletor de aço de $1,0 \mathrm{~m}^{2}$. As coletas ocorreram mensalmente de novembro de 2010 a junho de 2012. O material coletado foi triado, secado e pesado. A riqueza de espécies e a densidade de árvores foram obtidas através de estudo fitossociológico em 30 parcelas de $20 \mathrm{~m} \times 20 \mathrm{~m}$. Foi registrada uma produção de serapilheira de 3,673 $\mathrm{Mgha}^{-1} \mathrm{yr}^{-1}$, taxa condizente com os valores encontrados para florestas tropicais sazonalmente secas. A produção de serapilheira foi contínua entre os meses, acompanhando principalmente o efeito tardio da precipitação (dois a três meses anteriores) e apresentou maior deposição no período do início da estação seca e menor no chuvoso. As frações do material apresentaram taxas de contribuição distintas, sendo a de folha a maior contribuinte. A produção de serapilheira também foi relacionada com a densidade de árvores, porém não houve relação com a riqueza de espécies. A heterogeneidade temporal da produção de serapilheira evidencia a forte ligação entre as chuvas e a dinâmica de ciclagem de nutrientes na região semiárida do Brasil.
\end{abstract}

Palavras-chave: Caatinga, variabilidade espacial, variabilidade temporal, necromassa, região neotropical.

\section{Introduction}

Litterfall constitutes the most superficial layer of the soil and it is composed of leaves, stems, branches, fruits, flowers, and other plant parts, as well as animal

remains and fecal material - constituting a reserve of mineral elements and organic material that strongly influences the dynamics of ecosystem nutrient cycling 
(Coleman et al., 2004). Litterfall provides shading and helps retain humidity, creating micro-climatic conditions that can promote seed germination and seedling establishment (Moraes et al., 1998). The importance of litterfall goes beyond protecting and fertilizing the soil, as it directly affects local biodiversity conservation (Coleman et al., 2004). As such, studies focusing on the dynamics of litterfall are important to our understanding of nutrient cycling, forest growth, successional patterns, carbon cycling, ecological disturbances, and the interactions of environmental variables (Vasconcelos and Luizão, 2004; Zhou et al., 2007; González-Rodríguez et al., 2011).

Various biotic and abiotic factors (both environmental and spatial) affect litterfall production, such as the type of vegetation, altitude, latitude, temperature, light regime, moisture availability, and the physical and chemical characteristics of the soil (Bray and Gorham, 1964; Vitousek, 1984), with seasonal variations in the production and decomposition of litterfall being mainly related to climatic factors (Spain, 1984). In arid and semiarid ecosystems such as the Caatinga, litterfall has an important role in protecting the soil (Souto, 2006). The superficial leaf litter layer not only attenuate the intense solar radiation, but also aids in retaining moisture - as Caatinga soils have low infiltration capacities and therefore high rates of surface runoff (Souto, 2006; Moraes et al., 1998).

The Caatinga biome is one of the largest examples of semiarid savanna in the neotropical region, covering approximately $735,000 \mathrm{~km}^{2}$ in northeastern Brazil (AndradeLima, 1981; Leal et al., 2005). The regional landscape is dominated by a mosaic of different phytophysionomies, including arboreal, shrub, and thorny vegetations that are well-adapted to dry conditions (Coimbra-Filho and Câmara, 1996). The Caatinga environment is characterized by high levels of solar radiation during at least part of the year and sparse vegetation cover (Sampaio, 1995), with high evapotranspiration rates during the entire year (1500-2000 $\left.\mathrm{mmy}^{-1}\right)$ and low rainfall rates (300-1000 $\left.\mathrm{mmy}^{-1}\right)$; precipitation is normally concentrated into from 3 to 5 months - although rainfall patterns can be extremely erratic (Sampaio, 1995).

In light of the importance of litterfall to the dynamics of tropical ecosystems, especially semiarid regions, the present study sought to evaluate litterfall production rates in an area of Caatinga vegetation and examine their relationships with rainfall and vegetation structure (species richness and the density of individuals).

\section{Material and Methods}

The present study was undertaken on the Cauaçu Farm $\left(05^{\circ} 34^{\prime} 0.8^{\prime \prime} \mathrm{S}\right.$ and $\left.35^{\circ} 55^{\prime} 3.1^{\prime \prime} \mathrm{W}\right)$ that occupies approximately 700 ha in an area of Caatinga (dryland) vegetation in the municipality of João Câmara, Rio Grande do Norte State, in northeastern Brazil. The regional climate is semiarid, with a mean annual temperature of $24.7^{\circ} \mathrm{C}$ (minimum $21{ }^{\circ} \mathrm{C}$ and maximum $32{ }^{\circ} \mathrm{C}$ ), a mean annual rainfall rate of $648.6 \mathrm{~mm}$, and mean annual humidity of
$70 \%$. The rainy season normally extends between March and June (Brasil, 2005). The study site was situated at 100 to $200 \mathrm{~m}$ a.s.l.in an area of open to dense arboreal-shrub vegetation with scattered rock outcrops (the latter with its own low and very sparse vegetation).

The litterfall was collected on a monthly basis from November/2010 to June/2012 in a $2000 \mathrm{~m}$ x $500 \mathrm{~m}$ area. Thirty sampling points were randomly designated, and $20 \mathrm{~m} \times 20 \mathrm{~m}$ plots were established around them. At the center of each plot a $1.0 \mathrm{~m}^{2}$ collector was assembled, composed of a galvanized steel frame holding a nylon mesh $(1.0 \mathrm{~mm})$ suspended approximately $20 \mathrm{~cm}$ above the ground. The nylon mesh served to collect the falling litterfall without accumulating water (thus avoiding decomposition during the rainy season) (Costa et al., 2007).

The litterfall accumulated in the collector was harvested every month and manually sorted into different fractions: leaves (including leaflets and petioles), branches (including bark and other woody parts), reproductive structures (flowers, fruits and seeds), and miscellaneous material (which could not be precisely identified). After sorting, the different fractions were dried in a forced-air oven at $70{ }^{\circ} \mathrm{C}$ for $72 \mathrm{~h}$ and then weighed to four decimal-place accuracy using a precision balance. Rainfall data was provided by EMPARN (Agricultural Research Company of Rio Grande do Norte).

The species richness and densities in the plots were determined through phytosociological surveys (MuellerDombois and Ellenberg, 1974) that sampled all of the live individuals with stem diameters at soil level greater than or equal to $3.0 \mathrm{~cm}(\mathrm{DSL} \geq 3.0 \mathrm{~cm})$ and with total heights $\geq 1.0 \mathrm{~m}$ (Rodal, 1992).

One-way ANOVA testing was utilized to analyze the temporal variations in litterfall production, after confirming the homogeneity of the variances of the data. In order to conform to the requirements of normality, the litterfall production data was $\log (\mathrm{x}+1)$ transformed before analysis. Spearman's Correlation coefficient was used to evaluate the relationships between litterfall production and rainfall and the vegetation parameters (species richness and vegetation density). We evaluated the time lag influence of rainfall by considering precipitation levels during the second and third months previous to the collection of the litterfall material. Statistical calculations were performed using STATISTIC 5.0 software (Statsoft, 1995).

\section{Results}

The study area had a mean total litterfall production of $3.673 \mathrm{Mgha}^{-1} \mathrm{yr}^{-1}$, with a mean monthly production rate of ( \pm standard error) $0.306 \pm 0.03 \mathrm{Mgha}^{-1}$. There were significant variations in monthly total litterfall production rates $\left(\mathrm{F}_{19,580}=56.617, \mathrm{P}<0.001\right)$, with the greatest deposition rates in August (0.914 $\left.\mathrm{Mgha}^{-1}\right)$ and September/2011 (0.922 $\left.\mathrm{Mgha}^{-1}\right)$, while the smallest productions were observed in November $\left(0.039 \mathrm{Mgha}^{-1}\right)$ and December/2010 (0.021 $\left.\mathrm{Mgha}^{-1}\right)$ (Table 1). Leaves constituted the predominant fraction of the litterfall, 
Table 1. Monthly values of litterfall production at the Cauaçu farm located in the municipality of João Câmara, Rio Grande do Norte State, Brazil, during the period between November/ 2010 and June/ 2012. The values presented are the means \pm SE.

\begin{tabular}{|c|c|c|c|c|c|c|c|c|c|c|c|}
\hline \multicolumn{2}{|c|}{ Date } & \multicolumn{10}{|c|}{ Litterfall } \\
\hline \multirow{2}{*}{ Year } & \multirow{2}{*}{ Month } & \multicolumn{2}{|c|}{ Leaves } & \multicolumn{2}{|c|}{ Branches } & \multicolumn{2}{|c|}{ Flowers } & \multicolumn{2}{|c|}{ Miscellaneous } & \multicolumn{2}{|c|}{ Total } \\
\hline & & Mgha $^{-1}$ & SE & Mgha $^{-1}$ & SE & Mgha $^{-1}$ & SE & Mgha $^{-1}$ & SE & Mgha $^{-1}$ & SE \\
\hline \multirow[t]{2}{*}{2010} & Nov & 0.010 & $( \pm 0.002)$ & 0.021 & $( \pm 0.006)$ & 0.006 & $( \pm 0.002)$ & 0.002 & $( \pm 0.000)$ & 0.039 & $( \pm 0.068)$ \\
\hline & Dec & 0.005 & $( \pm 0.001)$ & 0.007 & $( \pm 0.002)$ & 0.004 & $( \pm 0.001)$ & 0.006 & & 0.021 & $( \pm 0.038)$ \\
\hline \multirow[t]{12}{*}{2011} & Jan & 0.046 & $( \pm 0.011)$ & 0.027 & $( \pm 0.003)$ & 0.004 & $( \pm 0.001)$ & 0.012 & $( \pm 0.002)$ & 0.089 & $( \pm 0.133)$ \\
\hline & Feb & 0.048 & $( \pm 0.007)$ & 0.041 & $( \pm 0.009)$ & 0.009 & $( \pm 0.003)$ & 0.007 & $( \pm 0.001)$ & 0.105 & $( \pm 0.161)$ \\
\hline & Mar & 0.148 & $( \pm 0.019)$ & 0.071 & $( \pm 0.013)$ & 0.021 & $( \pm 0.008)$ & 0.008 & $( \pm 0.002)$ & 0.249 & $( \pm 0.349)$ \\
\hline & Apr & 0.166 & $( \pm 0.018)$ & 0.072 & $( \pm 0.011)$ & 0.005 & $( \pm 0.001)$ & 0.012 & $( \pm 0.002)$ & 0.254 & $( \pm 0.342)$ \\
\hline & May & 0.151 & $( \pm 0.016)$ & 0.051 & $( \pm 0.008)$ & 0.004 & $( \pm 0.001)$ & 0.008 & $( \pm 0.001)$ & 0.214 & $( \pm 0.277)$ \\
\hline & Jun & 0.142 & $( \pm 0.017)$ & 0.033 & $( \pm 0.005)$ & 0.003 & $( \pm 0.001)$ & 0.005 & $( \pm 0.001)$ & 0.182 & $( \pm 0.222)$ \\
\hline & Jul & & $( \pm 0.038)$ & & $( \pm 0.009)$ & 0.005 & $( \pm 0.001)$ & 0.009 & $( \pm 0.002)$ & 0.386 & $( \pm 0.457)$ \\
\hline & Aug* & & $( \pm 0.069)$ & 0.115 & $( \pm 0.016)$ & 0.081 & $( \pm 0.021)$ & 0.005 & $( \pm 0.002)$ & 0.914 & $( \pm 1.115)$ \\
\hline & Sep* & 0.699 & $( \pm 0.072)$ & 0.162 & $( \pm 0.047)$ & 0.060 & $( \pm 0.009)$ & 0.000 & $( \pm 0.000)$ & 0.922 & $( \pm 1.144)$ \\
\hline & Oct & 0.224 & $( \pm 0.025)$ & 0.036 & $( \pm 0.005)$ & 0.037 & $( \pm 0.011)$ & 0.002 & $( \pm 0.001)$ & 0.299 & $( \pm 0.374)$ \\
\hline & Nov & 0.032 & $( \pm 0.008)$ & 0.035 & $( \pm 0.009)$ & 0.014 & $( \pm 0.002)$ & 0.001 & $( \pm 0.000)$ & 0.082 & $( \pm 0.132)$ \\
\hline & Dec & 0.012 & $( \pm 0.003)$ & 0.032 & $( \pm 0.009)$ & 0.008 & $( \pm 0.002)$ & 0.001 & $( \pm 0.000)$ & 0.053 & $( \pm 0.095)$ \\
\hline \multirow[t]{6}{*}{2012} & & 0.006 & $( \pm 0.002)$ & 0.050 & $( \pm 0.036)$ & 0.017 & & 0.003 & & 0.075 & $( \pm 0.145)$ \\
\hline & & 0.022 & $( \pm 0.003)$ & 0.029 & $( \pm 0.008)$ & 0.006 & $( \pm 0.001)$ & 0.003 & $( \pm 0.001)$ & 0.060 & $( \pm 0.098)$ \\
\hline & Mar & 0.044 & $( \pm 0.006)$ & 0.045 & $( \pm 0.011)$ & 0.016 & $( \pm 0.008)$ & 0.002 & $( \pm 0.001)$ & 0.107 & $( \pm 0.169)$ \\
\hline & Apr & 0.286 & $( \pm 0.052)$ & 0.038 & $( \pm 0.007)$ & 0.008 & $( \pm 0.005)$ & 0.005 & $( \pm 0.001)$ & 0.337 & $( \pm 0.388)$ \\
\hline & May & 0.337 & $( \pm 0.049)$ & 0.023 & $( \pm 0.007)$ & 0.005 & $( \pm 0.003)$ & 0.002 & $( \pm 0.001)$ & 0.366 & $( \pm 0.395)$ \\
\hline & Jun & 0.132 & $( \pm 0.013)$ & 0.016 & $( \pm 0.002)$ & 0.002 & $( \pm 0.001)$ & 0.000 & $( \pm 0.000)$ & 0.150 & $( \pm 0.168)$ \\
\hline \multicolumn{2}{|c|}{$\begin{array}{c}\text { Total } \\
\text { (in } 20 \text { months) }\end{array}$} & 3.537 & & 0.962 & & 0.312 & & 0.093 & & 4.904 & \\
\hline
\end{tabular}

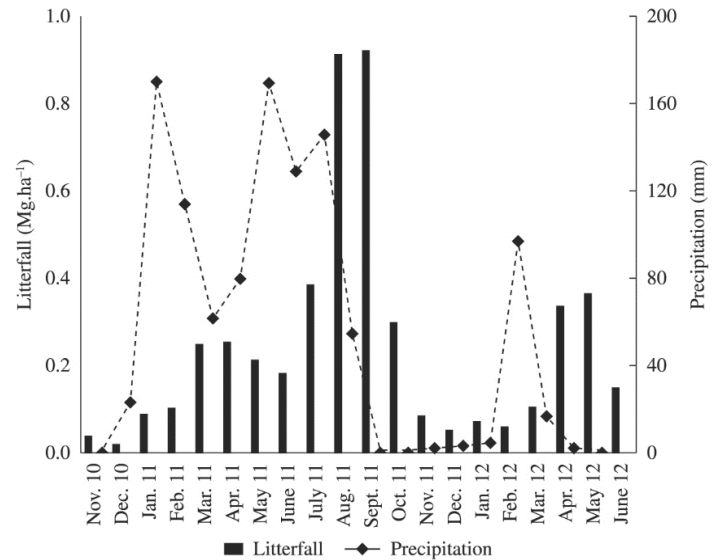

Figure 1. Temporal variations in litterfall production and precipitation during the period between November/ 2010 and June/ 2012 at the Cauaçu farm located in the municipality of João Câmara, Rio Grande do Norte State, Brazil.

generating approximately $72 \%$ of the total dry weight; branches represented approximately $20 \%$, with reproductive structures and miscellaneous materials representing approximately $6 \%$ and $2 \%$ respectively.
In the first year (November/2010 to October/2011), the total rainfall was approximately $950 \mathrm{~mm}$, with a monthly average of $56.81 \pm 14.48 \mathrm{~mm}$. Litterfall production was most highly correlated with the precipitation in the second and third months preceding the samplings $\left(\mathrm{r}_{\mathrm{s} 60 \text { days }}=0.821 ; \mathrm{n}=20\right.$; $\left.\mathrm{P}<0.001 ; \mathrm{r}_{\mathrm{s} 90 \text { days }}=0.748 ; \mathrm{n}=20 ; \mathrm{P}<0.001\right)$; no significant relationship was observed between litterfall production and rainfall in the 30 days immediately preceding the samplings $\left(\mathrm{r}_{\mathrm{s} 30 \text { days }}=0.439 ; \mathrm{n}=20 ; \mathrm{P}>0.05\right)$ (Figure 1$)$.

Species richness and vegetation densities varied from 3 to 15 species and from 130 to 920 individuals $\mathrm{ha}^{-1}$ respectively. Litterfall production was significantly correlated with vegetation density $\left(\mathrm{r}_{\mathrm{s}}=0.504 ; \mathrm{n}=27 ; \mathrm{P}=0.007\right)$ but not with species richness $\left(\mathrm{r}_{\mathrm{s}}=0.088 ; \mathrm{n}=27 ; \mathrm{P}=0.66\right)$.

\section{Discussion}

The total litterfall production recorded in the present study was within the range observed for seasonally dry tropical forests in Latin America, which varies between 2.8 and $8.5 \mathrm{Mgha}^{-1} \mathrm{yr}^{-1}$ (Jaramillo et al., 2011), but greater than litterfall values reported for other Caatinga areas (Alves et al., 2006; Souto, 2006; Costa et al., 2007; Santana and Souto 2011). Costa et al. (2010) and Santana (2005), for example, reported the deposition of $2.9 \mathrm{Mgha}^{-1} \mathrm{yr}^{-1}$ and 
2.1 $\mathrm{Mgha}^{-1} \mathrm{yr}^{-1}$ in two areas of Caatinga in Rio Grande do Norte State, while Lopes et al. (2009) reported the production of 2.8 $\mathrm{Mgha}^{-1} \mathrm{yr}^{-1}$ in a Caatinga site in Ceará State.

The different litterfall fractions all provided distinct contributions, with leaves dominating the total production ( $\sim 72 \%$ ), followed by branches, reproductive structures, and miscellaneous materials. According to Bray and Gorham (1964), leaves are consistently responsible for between $58 \%$ and $79 \%$ of all deciduous material, independent of the ecological zone considered. In areas of Caatinga vegetation, the leaf fraction has been observed to vary from 56.2\% to 80.6\% (Santana, 2005; Alves et al., 2006; Costa et al., 2007; Andrade et al., 2008; Lopes et al., 2009; Costa et al., 2010).

Martínez-Yrízar and Sarukhán (1990) reported a 17\% contribution of the branch fraction in a deciduous forest in Mexico, a value very similar to that seen in the present study (20\%), although the percentages reported from other regions around the world vary greatly. The reproductive structure fraction is directly related to the type of climate and to the phenologies of the dominant species (Lampe et al., 1992; Diniz and Pagano, 1997; Martínez-Yrízar et al., 1999; Alvarez et al., 2009). According to Amorim et al. (2009), wide variations in the flowering patterns of caatinga species have been noted, influencing the spatial patterns of reproductive structure productions.

The monthly production of litterfall demonstrated a marked seasonality accompanying the dry and rainy periods, with the greatest litter depositions in August and September/2011 (at the beginning of the dry season) and the lowest deposition in November and December/2010 (at the beginning of the rainy season). According to Delitti (1995), litterfall productions will have distinct relationships with rainfall patterns depending on the ecosystems in question. In Atlantic Forest and restinga (coastal, sandy soil vegetation) areas the greatest deposition of organic material occurs during the rainy season, while the greatest deposition in Cerrado and Caatinga areas occurs during the dry season (Delitti, 1995; Valenti et al., 2008).

The low litterfall production rates observed in Caatinga sites during the rainy season are due to the growth of new foliage, with the plants taking advantage of readily available water resources to produce new leaves and then accumulate nutrient reserves with their increased photosynthetic capacities (Souto, 2006). The peak of litterfall production at the beginning of the dry season is considered a preventative strategy to avoid water losses through transpiration during the following months of water stress (Meguro et al., 1979; Silva et al., 2004; Santana, 2005; Alves et al., 2006; Souto, 2006; Costa et al., 2007).

The variations in litterfall production among the sample plots were the result, at least in part, of differences in the densities of their plant species. Litterfall production rates reflect edaphic (Vitousek, 1984) and biological factors such as the structure of the vegetation (Schlittler et al., 1993; Werneck et al., 2001), its age (Leitão-Filho et al., 1993), and floristic composition (Sundarapandian and Swamy, 1999). The intensity with which each factor affects leaf litter accumulation is determined by the particular characteristics of each plant communities (Pires et al., 2006). The litterfall quantities in the sampling areas appeared to be the consequence of the particular characteristics of each habitat, and this spatial heterogeneity was observed in terms of total litterfall production as well as in relation to each of its component fractions (leaves, branches, reproductive structures, and miscellaneous).

In conclusion, the present study demonstrated that not only rainfall rates but also tree densities influence litterfall production in the Caatinga dryland region, and that the effects of rainfall are most evident after 60 to 90 days. In addition, our results corroborated that leaf fraction is the main component of litter in tropical communities (Bray and Gorham, 1964). As there are at least eight different ecoregions in the semiarid region of Brazil (Velloso et al., 2002), each with distinct characteristics in terms of their soils, vegetations and climates, litterfall production values would be expected to accompany these variations and accumulations will demonstrate strong spatial components.

\section{Acknowledgements}

The authors are grateful to Mr. Helder Emanuel for the logistic support during this research. In addition, the authors would like to thank the team at the "Laboratório de Ecologia e Conservação da Biodiversidade (LECOB) - UFRN" for their help with the field and laboratory work, as well as CAPES and CNPq for funding this project.

\section{References}

ALVAREZ, JA., VILLAGRA, PE., ROSSI, BE. and CESCA, E., 2009. Spatial and temporal litterfall heterogeneity generated by woody species in the Central Monte desert. Plant Ecology, vol. 205, no. 2, p. 295-303. http://dx.doi.org/10.1007/s11258-009-9618-z.

ALVES, AR., SOUTO, JS., SANTOS, RV. and CAMPOS, MCC. 2006. Decomposição de resíduos vegetais de espécies da Caatinga, na região de Patos, PB. Revista Brasileira de Ciências Agrárias, vol. 1 , no. 1, p. 57-63.

AMORIM, IL., SAMPAIO, EVSB. and ARAÚJO, EL., 2009. Fenologia de espécies lenhosas da caatinga do Seridó, RN. Revista Árvore, vol. 33, no. 3, p. 491-499. http://dx.doi.org/10.1590/ S0100-67622009000300011.

ANDRADE, RL., SOUTO, JS., SOUTO, PC. and BEZERRA, DM., 2008. Deposição de serrapilheira em área de caatinga na RPPN "Fazenda Tamanduá", Santa Terezinha-PB. Revista Caatinga, vol. 21, no. 2, p. 223-230.

ANDRADE-LIMA, D., 1981. The caatingas dominium. Revista Brasileira de Botanica. Brazilian Journal of Botany, vol. 4, no. 2, p. 149-153.

Brasil. Ministério de Minas e Energia, 2005. Projeto cadastro de fontes de abastecimento por água subterrânea do Rio Grande do Norte: diagnóstico do município de João Câmara. CPRM/ PRODEEM. Available from: <http://www.cprm.gov.br/rehi/atlas/ rgnorte/relatorios/JOCA065.PDF>. Access in: 01 Aug. 2015. 
BRAY, JR. and GORHAM, F., 1964. Litter production in forests of the world. Advances in Ecological Research, vol. 2, no. 2, p. 101-157. http://dx.doi.org/10.1016/S0065-2504(08)60331-1.

COIMBRA-FILHO, AF. and CÂMARA, IG., 1996. Os limites originais do bioma Mata Atlântica na região Nordeste do Brasil. Rio de Janeiro: Fundação Brasileira para Conservação da Natureza. 86 p.

COLEMAN, DC., CROSSLEY JUNIOR, DA. and HENDRIX, PF., 2004. Fundamentals of soil ecology. 2nd ed. San Diego: Elsevier Academic Press. p. 384.

COSTA, CCA., CAMACHO, RGV., MACEDO, ID. and SILVA, PCM., 2010. Análise comparativa da produção de serapilheira em fragmentos arbóreos e arbustivos em área de Caatinga na Flona de Açu-RN. Revista Árvore, vol. 34, no. 2, p. 259-265. http:// dx.doi.org/10.1590/S0100-67622010000200008.

COSTA, CCA., SOUZA, AM., SILVA, NF., CAMACHO, RGV. and DANTAS, IM., 2007. Produção de serapilheira na Caatinga da Floresta Nacional do Açú-RN. Revista Brasileira de Biociências, vol. 5, supplement 1, p. 246-248.

DELITTI, WBC., 1995. Estudos de ciclagem de nutrientes: instrumentos para analise funcional de ecossistemas terrestres. Oecologia Brasiliensis, vol. 1, no. 1, p. 469-483.

DINIZ, S. and PAGANO, SN., 1997. Dinâmica de folhedo em floresta mesófila semidecídua no município de Araras, SP. I - Produção, Decomposição e Acúmulo. Revista do Instituto Florestal, vol. 9, no. 1, p. 27-36.

GONZÁLEZ-RODRÍGUEZ, H., DOMÍNGUEZ-GÓMEZ, TG., CANTÚ-SILVA, I., GÓMEZ-MEZA, MV., RAMÍREZ-LOZANO, RG., PANDO-MORENO, M. and FERNÁNDEZ, CJ., 2011. Litterfall deposition and leaf litter nutrient return in different locations at Northeastern Mexico. Plant Ecology, vol. 212, no. 10, p. 1747-1757. http://dx.doi.org/10.1007/s11258-011-9952-9.

JARAMILLO, VJ., MARTÍNEZ-YRÍZAR, A. and SANFORD JUNIOR, RL. 2011. Primary productivity and biogeochemistry of seasonally dry tropical forests. In DIRZO, R., YOUNG, HS., MOONEY, HA. and CEBALlOS, G. (Eds.). Seasonally dry tropical forests: ecology and conservation. Washington: Island Press. p. 109-128.

LAMPE, MG., BERGERON, Y., MCNEIL, R. and LEDUC, A., 1992. Seasonal flowering and fruiting pattern in tropical semiarid vegetation of northeast Venezuela. Biotropica, vol. 24, no. 1, p. 64-76. http://dx.doi.org/10.2307/2388474.

LEAL, IR., SILVA, JMC., TABARELLI, M. and LACHER, TE., 2005. Changing the course of biodivesity conservation in the Caatinga of Northeastern Brazil. Conservation Biology, vol. 19, no. 3, p. 701-706. http://dx.doi.org/10.1111/j.1523-1739.2005.00703.x.

LEITÃO-FILHO, HF., PAGANO, SN., CÉSAR, O., TIMONI, JL. and RUEDA, JJ. 1993. Aspectos da ciclagem de nutrientes. In LEITÃO-FILHO, HF. (Ed.). Ecologia da mata Atlântica em Cubatão. São Paulo: Editora da Universidade Estadual Paulista/ Editora da Universidade de Campinas. p. 129-163.

LOPES, JFB, ANDRADE, EM., LOBATO, FAO., PALACIO, HAQ. and ARRAES, FDD., 2009. Deposição e decomposição de serrapilheira em área da Caatinga. Revista Agroambiente, vol. 3 , no. 2 , p. $72-79$.

MARTÍNEZ-YRÍZAR, A. and SARUKHÁN, J., 1990. Litterfall patterns in a tropical deciduous forest in Mexico over a five-year period. Journal of Tropical Ecology, vol. 6, no. 4, p. 433-444. http://dx.doi.org/10.1017/S0266467400004831.
MARTÍNEZ-YRÍZAR, A., NÚÑEZ, S., MIRANDA, H. and BÚRQUEZ, A., 1999. Temporal and spatial variation of litter production in Sonoran Desert communities. Plant Ecology, vol. 145, no. 1, p. 37-48. http://dx.doi.org/10.1023/A:1009896201047.

MEGURO, M., VINUEZA, GN. and DELITTI, WBC., 1979. Ciclagem de nutrientes minerais na mata mesófila secundária. São Paulo. I. O papel da precipitação na importação e transferência de potássio e fósforo. Boletim de Botânica, vol. 7, p. 61-67. http:// dx.doi.org/10.11606/issn.2316-9052.v7i0p61-67.

MORAES, RM., DELITTI, WBC., RINALDI, MCS. and REBELO, CF. 1998. Ciclagem mineral em Mata Atlântica de encosta e mata sobre restinga, Ilha do Cardoso, SP: nutrientes na serapilheira acumulada. In Anais do IV Simpósio de Ecossistemas Brasileiros, 1998. Águas de Lindóia. São Paulo: Academia de Ciências do Estado de São Paulo. vol. 2. p. 71-77.

MUELLER-DOMBOIS, D. and ELLENBERG, H., 1974. Aims and methods of vegetation ecology. New York: John Willey and Sons. $547 \mathrm{p}$.

PIRES, LA., BRITEZ, RM., MARTEL, G. and PAGANO, SN., 2006. Produção, acúmulo e decomposição da serrapilheira em uma restinga da Ilha do Mel, Paranaguá, PR, Brasil. Acta Botanica Brasílica, vol. 20, no. 1, p. 173-184. http://dx.doi.org/10.1590/ S0102-33062006000100016.

RODAL, MJN., 1992. Fitossociologia da vegetação arbustivoarbórea em quatro áreas de caatinga em Pernambuco. Campinas: Universidade Estadual de Campinas. 198 p. Doctoral thesis in Plant Biology.

SAMPAIO, EVSB., 1995. Overview of the Brazilian caatinga. In BULLOCK, S., MOONEY, HA. and MEDINA, E. (Eds.). Seasonally dry tropical forests. Cambridge: University Press. p. 35-58.

SANTANA, JAS., 2005. Estrutura fitossociológica, produção de serrapilheira e ciclagem de nutrientes em uma área de Caatinga no Seridó do Rio Grande do Norte. Areia: Universidade Federal da Paraíba. 184 p. Doctoral thesis in Agronomy.

SANTANA, JAS. and SOUTO, JS., 2011. Produção de serrapilheira na caatinga da região semiárida do Rio Grande do Norte, Brasil. Idesia, vol. 29, no. 2, p. 87-94. http://dx.doi.org/10.4067/S071834292011000200011.

SCHLITTLER, FHM., DE MARINIS, G. and CÉSAR, O., 1993. Produção de serrapilheira na Floresta do Morro do Diabo, Pontal do Paranapanema-SP. Naturalia (São José do Rio Preto), vol. 18 , no. 12 , p. $135-147$.

SILVA, JMC., TABARELLI, M., FONSECA, MT. and LINS, L., 2004. Biodiversidade da Caatinga: áreas prioritárias para conservação. Brasília: Ministério do Meio Ambiente. 382 p.

SOUTO, PC., 2006. Acumulação e decomposição da serrapilheira e distribuição de organismos edáficos em área de caatinga na Paraíba, Brasil. Areia: Universidade Federal da Paraíba. 145 p. Doctoral thesis in Agronomy.

SPAIN, AV., 1984. Litterfall and the standing crop of litter in three tropical Australian rainforests. Journal of Ecology, vol. 72, no. 3, p. 947-961. http://dx.doi.org/10.2307/2259543.

Statsoft, 1995. Statistic. Tulsa: Statsoft Inc. Version 5.0.

SUNDARAPANDIAN, SM. and SWAMY, PS., 1999. Litter production and leaf-litter decomposition of selected tree species in tropical forests at Kodayar in the Western Ghats, India. Forest 
Ecology and Management, vol. 123, no. 2-3, p. 231-244. http:// dx.doi.org/10.1016/S0378-1127(99)00062-6.

VALENTI, MW., CIANCIARUSO, MV. and BATALHA, MA., 2008. Seasonality of litterfall and leaf decomposition in a cerrado site. Brazilian Journal of Biology = Revista Brasileira de Biologia, vol. 68, no. 3, p. 459-465. http://dx.doi.org/10.1590/ S1519-69842008000300002. PMid:18833466.

VASCONCELOS, HL. and LUIZÃO, FJ., 2004. Litter production and litter nutrient concentrations in a fragmented Amazonian landscape. Ecological Applications, vol. 14, no. 3, p. 884-892. http://dx.doi.org/10.1890/03-5093.

VELLOSO, AL., SAMPAIO, EVSB. and PAREYN, FGC., 2002. Ecorregiões propostas para o bioma Caatinga. Recife: Associação Plantas do Nordeste/ Instituto de Conservação Ambiental The Nature Conservancy do Brasil. $76 \mathrm{p}$.
VITOUSEK, PM., 1984. Litterfall, nutrient cycling and nutrient limitation in tropical forests. Ecology, vol. 65, no. 1, p. 285-298. http://dx.doi.org/10.2307/1939481

WERNECK, MS., PEDRALLI, G. and GIESEKE, LF., 2001. Produção de serrapilheira em três trechos de uma floresta semidecídua com diferentes graus de perturbação na Estação Ecológica do Tripuí, Ouro Preto, MG. Revista Brasileira de Botanica. Brazilian Journal of Botany, vol. 24, no. 2, p. 195-198. http://dx.doi.org/10.1590/S0100-84042001000200009.

ZHOU, G., GUAN, L., WEI, X., ZHANG, D., ZHANG, Q., YAN, J., WEN, D., LIU, J., LIU, S., HUANG, Z., KONG, G., MO, J. and YU, A., 2007. Litterfall production along successional and altitudinal gradients of subtropical monsoon evergreen broadleaved forests in Guangdong, China. Plant Ecology, vol. 188, no. 1, p. 77-89. http://dx.doi.org/10.1007/s11258-006-9149-9. 